\title{
ACTIVITY BASED COSTING SYSTEM SEBAGAI ALTERNATIF PENETAPAN TARIF JASA RAWAT INAP SERTA IMPLIKASINYA TERHADAP PENDAPATAN RSUD KABUPATEN BULELENG
}

\author{
I Gd Nandra Hary Wiguna \\ Universitas Pendidikan Ganesha, Jalan Udayana 11, Singaraja-Bali, \\ Indonesia \\ (harywiguna@gmail.com)
}

\begin{abstract}
ABSTRAK
Penelitian ini bertujuan untuk mengetahui penerapan tarif jasa dengan menggunakan Activity Based Costing System (ABC) serta implikasinya terhadap pendapatan rawat inap pada RSUD Kabupaten Buleleng. Penelitian ini adalah penelitian komparatif dan kausal. Objek penelitian ini adalah laporan perhitungan tarif rawat inap dengan metode tradisional, laporan biaya-biaya, dan laporan pendapatan rawat inap RSUD Kabupaten Buleleng tahun 2016. Data yang dikumpulkan adalah data sekunder dengan menggunakan metode dokumentasi. Berdasarkan uji statistik menggunakan uji $t$ dua sampel diketahui bahwa tarif jasa rawat inap dengan metode tradisional dan metode ABC memiliki perbedaan yang signifikan. Uji koefisien korelasi dan koefisien determinasi menunjukkan bahwa penerapan tarif jasa rawat inap metode ABC memberikan pengaruh yang positif terhadap pendapatan rawat inap rumah sakit. Hal ini menunjukkan apabila tarif jasa rawat inap mengalami kenaikan atau penurunan maka pendapatan rawat inap juga akan mengalami kenaikan atau penurunan.
\end{abstract}

Kata kunci: Activity Based Costing System, Metode Tradisional, Pendapatan

\begin{abstract}
This study aimed at determining the tariff application services using Activity Based Costing System (ABC) and its implications on revenues of hospitalized patient in general hospital in Buleleng regency. This research was comparative and causal. Objects of this study were the calculation of hospitalization rates reported the traditional methods, costs, and income statements of the hospitalized patients in general 2016. The secondary were collected by using documentation. Based on the statistical tests used by using two-sample t test, it was found out that the rate of hospitalization services to the traditional method and the $A B C$ method was a significant. Test of the correlation coefficient and the coefficient of determination indicated that the applied rates of hospitalization services done by the used of the traditional method and the $A B C$ method positive on the revenues of the hospitalized patients. This indicated that if the hospital service rates increased or decreased would also increase or decreased.
\end{abstract}

Keywords: Activity Based Costing System, Traditional Methods, Revenues 


\section{PENDAHULUAN}

Rumah sakit adalah salah satu contoh organisasi berorientasi nonprofit. Rumah sakit merupakan suatu organisasi yang memberikan pelayanan kesehatan yang bersifat sosial. Rumah sakit mempunyai tugas utama memberikan pengobatan, perawatan kepada pasien, dan pelayanan kesehatan kepada masyarakat.

Dalam memberikan jasa pelayanan kesehatan, rumah sakit memperoleh penghasilan dari pendapatan jasa dan fasilitas yang diberikan. Salah satunya adalah jasa rawat inap. Pendapatan yang berasal dari jasa tersebut didapat dari tarif yang harus dibayar oleh pemakai jasa rawat inap. Penentuan tarif jasa rawat inap merupakan suatu keputusan yang sangat penting. Karena dapat mempengaruhi profitabilitas suatu rumah sakit. Kondisi ini menuntut pihak manajemen rumah sakit mampu memikirkan strategi rumah sakit ke depannya agar mampu bersaing dengan rumah sakit lainnya. Berbagai macam aktivitas pada jasa rawat inap, serta jumlah biaya overhead yang tinggi, menuntut ketepatan dalam pembebanan biaya yang sesungguhnya.

Dalam menentukan tarif rawat inap terkadang rumah sakit masih menggunakan akuntansi biaya tradisional, yang penentuan harga pokoknya tidak lagi mencerminkan aktivitas yang spesifik karena banyaknya kategori biaya yang bersifat tidak langsung. Sistem seperti ini tidak sesuai dengan lingkungan pemanufakturan maju (advanced manufacturing environment), yang ingin mencapai keunggulan daya saing yang kuat, sistem akuntansi juga harus diubah untuk mengikuti perkembangan (Supriyono, 2002:219). Sistem tradisional juga menyebabkan biaya produk yang dihasilkan memberikan informasi biaya produksi yang terdistorsi yaitu undercosting atau overcosting. Menurut Horngren, Datar, Foster (2008:165) kekurangan biaya (undercosting) adalah sebuah produk membutuhkan sumber daya dalam jumlah banyak tetapi justru memiliki biaya per unit yang rendah, sedangkan kelebihan biaya (overcosting) adalah sebuah produk mengkonsumsi sumber daya dalam jumlah sedikit tetapi justru memiliki biaya per unit yang tinggi. Distorsi tersebut mengakibatkan kesalahan pengambilan keputusan dalam hal harga produk dan kelangsungan organisasi. Distorsi timbul karena adanya ketidakakuratan dalam pembebanan biaya, sehingga mengakibatkan kesalahan penentuan biaya, pembuatan keputusan, perencanaan, dan pengendalian. 
Sehingga perlu diterapkannya sistem penentuan harga pokok produk berdasarkan aktivitasnya (activity based) atau yang dikenal dengan Activity Based Costing System (ABC).

Metode ABC merupakan sebuah sistem informasi akuntansi yang mengidentifikasikan bermacammacam aktivitas yang dikerjakan didalam suatu organisasi dan mengumpulkan biaya dengan dasar sifat yang ada dari aktivitas tersebut. Menurut Hansen \& Mowen (2009:175), ABC merupakan suatu sistem perhitungan biaya yang pertama kali menelusuri biaya pada aktivitas dan kemudian pada produk.

Rumah Sakit Umum Daerah Kabupaten Buleleng merupakan rumah sakit yang masih menggunakan metode tradisional dalam penentuan tarif jasa rawat inapnya. Kepala keuangan RSUD menyampaikan bahwa penetapan tarif jasa rawat inap dengan metode tradisional yang telah digunakan puluhan tahun ini dirasa menjadi penyebab tidak naksimalnya pendapatan Rumah Sakit dari sektor jasa rawat inap. Dari kondisi tersebut dirasa perlu dilakukan penelitian dengan menggunakan metode yang lebih evektif seperti ABC sistem ini dalam penetapan tarif jasa rawat inap di RSUD Kabupaten Buleleng.

\section{TELAAH LITERATUR DAN PERUMUSAN HIPOTESIS}

\section{Akuntansi Biaya}

Akuntansi biaya adalah suatu sistem informasi yang menghasilkan informasi biaya dan informasi operasi suatu organisasi atau perusahaan yang digunakan sebagai dasar dalam pengukuran, penganalisis, pelaporkan, dan pengambilan keputusan (Mulyadi, 2014:7). Menurut (Supriyono, 2012:12) informasi biaya yang dihasilkan oleh akuntansi biaya sangat bermanfaat bagi manajemen perusahaan karena sebagai dasar pengambilan keputusan manajemen dalam mencapai tujuan perusahaan. akuntansi biaya mempunyai tiga tujuan pokok: penentuan kos produk, pengendalian biaya, dan pengambilan keputusan khusus.

$$
\text { Untuk memenuhi tujuan }
$$
penentuan kos produk, akuntansi mencatat, menggolongkan, dan meringkas biaya-biaya pembuatan produk atau penyerahan jasa. Pengendalian biaya harus didahului dengan penentuan biaya yang seharusnya dikeluarkan untuk memproduksi satu satuan produk. Pengambilan keputusan khusus menyangkut masa yang akan datang (Mulyadi, 2012:7-8). 
Activity Based Costing System

Menurut Amin Wijaya Tunggal (2009:2) Activity-Based Costing adalah: "Metode costing yang mendasarkan pada aktivitas yang didesain untuk memberikan informasi biaya kepada para manajer untuk pembuatan keputusan stratejik dan keputusan lain yang mempengaruhi kapasitas dan biaya tetap". Hansen \& Mowen (2009:175) menyatakan "Metode Activity-Based Costing (ABC) merupakan suatu sistem perhitungan biaya yang pertama kali menelusuri biaya pada aktivitas dan kemudian pada produk".

ABC (Activity Based Costing
System) adalah suatu metode perhitungan biaya produksi yang membebankan biaya melalui aktivitas-aktivitas penyebab terjadinya biaya. (Kamaruddin, 2013:13). Melalui ABC sistem diharapkan dapat membantu para manajer untuk mengurangi aktivitasaktivitas yang memberikan nilai tambah sehingga perusahaan dapat menawarkan produknya dengan harga yang kompetitif (Blocher, dkk,2011:206).

$$
\text { Supriyono }
$$

mengemukakan tentang keunggulan metode Activity Based Costing System adalah sebagai berikut:

\section{Memperbaiki mutu} pengambilan keputusan.
Dengan informasi biaya produk yang lebih teliti, kemungkinan manajer melakukan pengambilan keputusan yang salah dapat dikurangi. Informasi biaya produk yang lebih teliti sangat penting.

2. Memungkinkan manajemen melakukan perbaikan terusmenerus terhadap kegiatan untuk mengurangi biaya overhead.

3. Memberikan kemudahan dalam menentukan biaya relevan.

4. Suatu pengkajian ABC dapat meyakinkan manajemen bahwa mereka harus mengambil sejumlah langkah untuk menjadi lebih kompetitif.

5. ABC membantu dalam pengambilan keputusan.

6. Manajemen akan berada dalam suatu posisi untuk melakukan penawaran kompetitif yang lebih wajar.

7. Melalui analisis data biaya dan pola konsumsi sumber daya, manajemen dapat mulai merekayasa kembali proses manufakturing untuk mencapai pola keluaran mutu yang lebih efisien dan lebih tinggi.

8. ABC mengatasi adanya distorsi informasi atas biaya produk 
yang dibebankan yang dihasilkan dari sistem pembebanan biaya tradisional.

9. ABC lebih memberikan informasi yang akurat mengenai biaya-biaya yang muncul dan dibebankan kepada produk, terutama bagi perusahaan yang memiliki volume produksi tinggi dan diversifikasi produk yang beraneka ragam.

\section{Cost Driver}

Menurut Cooper \& Kaplan (1991:375), penentuan banyaknya cost driver yang dibutuhkan berdasarkan pada keakuratan laporan product cost yang diinginkan dan kompleksitas komposisi output perusahaan. Semakin banyak cost driver yang digunakan, laporan biaya produksi semakin akurat. Dengan kata lain semakin tinggi tingkat keakuratan yang diinginkan, semakin banyak cost driver yang dibutuhkan. Menurut Supriyono (2002:221) Cost driver merupakan faktor-faktor penyebab yang menjelaskan konsumsi overhead. Faktor ini menunjukkan suatu penyebab utama tingkat aktivitas yang akan menyebabkan biaya dalam aktivitas.

\section{Sistem Akuntansi Biaya Tradisional}

Akuntansi biaya tradisional terdiri atas tiga elemen yaitu biaya bahan baku, biaya tenaga kerja langsung dan biaya overhead pabrik. Biaya bahanbaku dan biaya tenaga kerja langsung merupakan biaya langsung sehingga tidak menimbulkan masalah pembebanan produk. Sistem tradisional bisa merupakan sistem perhitungan satu atau dua tahap. Sistem biaya tradisional menggunakan dua tahap hanya apabila jika departemen atau pusat biaya lain dibuat (Carter, 2009:533)

Perhitungan biaya produk dalam sistem biaya tradisional menggunakan penggerak aktivitas tingkat unit (unit level activity driver). "Penggerak aktivitas tingkat unit (unit level activity driver) adalah faktorfaktor yang menyebabkan perubahan dalam biaya seiring dengan perubahan jumlah unit yang diproduksi" (Hansen \& Mowen, 2009:162).

Menurut Supriyono (2002:74-77) kelemahan metode tradisional adalah sebagai berikut:

1. Sistem akuntansi biaya tradisional terlalu menekankan pada tujuan penentuan harga pokok produk yang dijual.

2. Sistem akuntansi biaya tradisional untuk biaya overhead terlalu memusatkan pada distribusi dan alokasi biaya overhead. 
3. Sistem akuntansi biaya tradisional tidak mencerminkan sebab akibat biaya karena seringkali beranggapan bahwa biaya ditimbulkan oleh faktor tunggal misalnya volume produk atau jam kerja langsung.

4. Sistem akuntansi biaya tradisional menghasilkan informasi biaya yang terdistorsi sehingga mengakibatkan pembuatan keputusan yang menimbulkan konflik dengan keunggulan perusahaan.

5. Sistem akuntansi biaya tradisional menggolongkan biaya langsung dan tidak langsung serta biaya tetap dan variabel hanya mendasarkan faktor penyebab tunggal misalnya volume produk.

6. Sistem akuntansi biaya tradisional menggolongkan suatu perusahaan kedalam pusat-pusat pertanggung jawaban yang kaku dan terlalu menekankan kinerja jangka pendek.

7. Sistem akuntansi biaya tradisional memusatkan perhatian kepada perhitungan selisih biaya pusat-pusat pertanggungjawaban tertentu dengan menggunakan standar.
8. Sistem akuntansi biaya tradisional tidak banyak memerlukan alat-alat dan teknik-teknik yang canggih dalam sistem informasi dibandingkan pada lingkungan teknologi maju.

9. Sistem akuntansi biaya tradisional kurang menekankan pentingnya daur hidup produk.

\section{Perbedaan Tarif Rawat Inap Rumah} Sakit dengan Menggunakan Metode Tradisional dan Metode ABC.

Menurut Supriyono (2002:219) sistem tradisional sudah tidak sesuai dengan lingkungan pemanufakturan maju (advanced manufacturing environment), yang ingin mencapai keunggulan daya saing yang kuat, sistem akuntansi juga harus diubah untuk mengikuti perkembangan. Selain itu sistem tradisional menyebabkan biaya produk yang dihasilkan memberikan informasi biaya produksi yang terdistorsi yaitu undercosting atau overcosting (Hansen \& Mowen, 2005).

Menurut Horngren, Datar, Foster (2008:165) kekurangan biaya (undercosting) adalah sebuah produk membutuhkan sumber daya dalam jumlah banyak tetapi justru memiliki biaya per unit yang rendah, sedangkan kelebihan biaya 
(overcosting) adalah sebuah produk mengkonsumsi sumber daya dalam jumlah sedikit tetapi justru memiliki biaya per unit yang tinggi. Distorsi tersebut mengakibatkan kesalahan pengambilan keputusan dalam hal harga produk dan kelangsungan organisasi. Penelitian Fieda Femala (2007), menunjukkan bahwa perhitungan tarif rawat inap dengan menggunakan metode $\mathrm{ABC}$, apabila dibandingkan dengan metode tradisional maka metode ABC memberikan hasil yang lebih besar kecuali pada kelas VIP dan Utama I yang memberikan hasil yang lebih kecil.

Hal ini disebabkan karena pembebanan biaya overhead pada masing-masing produk. Pada metode akuntansi biaya tradisional biaya overhead pada masing-masing produk hanya dibebankan pada satu cost driver saja. Sedangkan pada metode $\mathrm{ABC}$, biaya overhead pada masingmasing produk dibebankan pada banyak cost driver. Yulianti (2011) menyatakan besarnya tarif jasa rawat inap untuk berbagai kelas. Dari hasil perhitungan tarif rawat inap dengan menggunakan ABC apabila dibandingkan dengan tarif rawat inap yang digunakan oleh rumah sakit yaitu metode tradisional terlihat beberapa kelas memberikan hasil yang lebih besar kecuali pada kelas I, kelas II, dan kelas III memberikan hasil yang lebih kecil. Pada penelitian ini disampaikan bahwa $\mathrm{ABC}$ telah mampu mengalokasikan biaya aktivitas ke setiap kamar secara tepat berdasarkan konsumsi masingmasing aktivitas. Amirah Said Baashen (2011) juga menunjukkan bahwa penerapan tarif rawat inap dengan menggunakan metode tradisional dan metode $\mathrm{ABC}$ memiliki perbedaan.

H1: Terdapat perbedaan yang signifikan antara tarif jasa rawat inap rumah sakit dengan metode tradisional dan metode $\mathrm{ABC}$.

\section{Pengaruh Penetapan Tarif Rawat Inap dengan Menggunakan Metode ABC terhadap Pendapatan Rawat Inap Rumah Sakit}

Penelitian yang dilakukan oleh Amirah Said Baashen (2011) selain menunjukkan bahwa penerapan tarif rawat inap rumah sakit dengan menggunakan metode tradisional dan metode ABC memiliki perbedaan, hasil penelitian ini juga menemukan adanya pengaruh antara penetapan tarif dengan metode tradisional dan metode ABC terhadap pendapatan rawat inap rumah sakit. Berdasarkan uji statistik yang dilakukan dapat diketahui bahwa penerapan tarif jasa rawat inap rumah sakit dengan menggunakan metode tradisional 
dan metode $\mathrm{ABC}$ memiliki pengaruh terhadap pendapatan rawat inap rumah sakit. Dari hasil penelitian diatas dapat disimpulkan bahwa penentuan tarif rawat inap rumah sakit dengan menggunakan metode ABC sistem akan memberikan pengaruh terhadap pendapatan rawat inap rumah sakit. Maka dapat dibentuk hipotesis berikut:

H2: Tarif jasa rawat inap dengan metode ABC berpengaruh terhadap pendapatan rawat inap rumah sakit

\section{METODE}

\section{Rancangan Penelitian}

Penelitian ini termasuk dalam jenis penelitian dengan pendekatan kuantitatif. Penelitian ini digolongkan dalam penelitian komparatif dan kausal. Pada penelitian ini akan dilakukan perhitungan tarif rawat inap dengan metode $\mathrm{ABC}$, kemudian melakukan perbandingan tarif rawat inap dengan metode tradisional dan metode ABC, setelah itu akan dianalisis bagaimana hubungan dan pengaruh tarif rawat inap dengan metode tradisional dan metode $\mathrm{ABC}$ terhadap pendapatan rumah sakit.

\section{Populasi dan Sampel Penelitian}

Populasi dalam penelitian ini adalah data mengenai perhitungan unit cost untuk layanan rawat inap, laporan biaya-biaya yang berhubungan dengan penetapan tarif inap, dan laporan pendapatan rawat inap rumah sakit. Sampel yang akan diambil dalam penelitian ini yaitu data mengenai perhitungan unit cost layanan rawat inap sejumlah kelas kamar dan biaya-biaya yang menjadi dasar penetapan tarif rawat inap pada tahun 2016.

\section{Teknik Pengumpulan Data}

Metode pengumpulan data yang digunakan dalam penelitian ini adalah dokumentasi. Data yang diambil berupa data tarif rawat inap rumah sakit yang masih menggunakan metode tradisional pada masing-masing kelas perawatan, data biaya-biaya yang menjadi dasar penentuan tarif rawat inap rumah sakit tahun 2016.

\section{Teknik Analisis Data}

1. Menghitung tarif jasa rawat inap RSUD Kabupaten Buleleng dengan metode ABC sistem untuk tahun 2016 sesuai dengan prosedur (Cost Plus Pricing).

2. Menghitung pendapatan jasa rawat inap RSUD Kabupaten Buleleng dengan metode ABC sistem untuk tahun 2016. Pendapatan dalam unit jasa rawat inap dapat diperoleh dengan mengalikan antara tarif rawat inap yang dibebankan 
kepada pasien dengan lama hari rawat inap pasien tersebut di rumah sakit.

3. Melakukan uji statistik dengan t-test untuk mengetahui ada tidaknya perbedaan yang signifikan antara tarif jasa layanan rawat inap RSUD Kabupaten Buleleng yang diterapkan tahun 2016 dengan menggunakan metode tradisional dan metode $\mathrm{ABC}$.

4. Melakukan uji koefisien korelasi dan koefisien determinasi untuk mengetahui pengaruh penerapan tarif jasa layanan rawat inap RSUD Kabupaten Buleleng dengan menggunakan metode tradisional dan metode $\mathrm{ABC}$ terhadap pendapatan rawat inap rumah sakit.

\section{HASIL DAN PEMBAHASAN}

\section{Hasil Penelitian}

Penerapan tarif jasa rawat inap pada RSUD Kabupaten Buleleng berdasarkan metode ABC adalah sebagai berikut:

Tabel 1. Jenis Aktivitas dan Penyebab Biaya

\begin{tabular}{cll}
\hline No. & \multicolumn{1}{c}{ Aktivitas } & \multicolumn{1}{c}{ Penyebab Biaya } \\
\hline 1 & Aktivitas Penerimaan Pasien & Biaya ATK \\
2 & Aktivitas Perawatan Pasien & Biaya Gaji \\
3 & Aktivitas Pemeliharaan Pasien & Biaya Gizi \\
& & Biaya Habis Pakai Umum \\
4 & Aktivitas Pelayanan Pasien & Biaya Linen \\
5 & Aktivitas Peningkatan Pelayanan Pasien & Biaya Listrik, Air, Telepon \\
& & Biaya Diklat \\
& & Biaya Penyusutan Gedung \\
& & Biaya Penyusutan Fasilitas \\
6 & Aktivitas Pemeliharaan Inventaris & Biaya Pemeliharaan Gedung \\
& & Biaya Pemeliharaan Fasilitas \\
\end{tabular}

Tabel 2. Pengklasifikasian Biaya

\begin{tabular}{ll}
\hline \multicolumn{1}{c}{ Biaya Langsung } & \multicolumn{1}{c}{ Biaya Tidak Langsung } \\
\hline Biaya Habis Pakai Umum & Biaya ATK \\
Biaya Gizi & Biaya Linen \\
Biaya Gaji & Biaya Listrik \\
& Biaya Air \\
& Biaya Telepon \\
& Biaya Penyusutan Gedung \\
& Biaya Penyusutan Fasilitas \\
& Biaya Pemeliharaan Gedung \\
& Biaya Pemeliharaan Fasilitas \\
& Biaya Kebersihan \\
& Biaya Diklat \\
\hline
\end{tabular}


Tabel 3. Jumlah Biaya Rawat Inap RSUD Kabupaten Buleleng Tahun 2016

\begin{tabular}{clr}
\hline No. & \multicolumn{1}{c}{ Elemen Biaya } & Jumlah $(\mathrm{Rp})$ \\
\hline 1 & Biaya Gaji & $544.320 .000,00$ \\
2 & Biaya Bahan Habis Pakai Umum & $271.859 .372,00$ \\
3 & Biaya Gizi & $1.638 .611 .326,00$ \\
4 & Biaya ATK & $27.369 .078,00$ \\
5 & Biaya Linen & $398.442 .500,00$ \\
6 & Biaya Listrik & $76.049 .248,00$ \\
7 & Biaya Air & $146.077 .244,00$ \\
8 & Biaya Telepon & $29.136 .060,00$ \\
9 & Biaya Diklat & $56.745 .000,00$ \\
10 & Biaya Penyusutan Gedung & $280.078 .551,00$ \\
11 & Biaya Penyusutan Fasilitas & $468.304 .254,00$ \\
12 & Biaya Pemeliharaan Gedung & $63.317 .739,00$ \\
13 & Biaya Pemeliharaan Fasilitas & $72.369 .278,00$ \\
14 & Biaya Kebersihan & $68.545 .690,00$ \\
\hline
\end{tabular}

Tabel 4. Pengklasifikasian Kelompok Aktivitas

\begin{tabular}{lr}
\hline Elemen Biaya & Jumlah Biaya (Rp) \\
\hline Unit Level Activity Cost & \\
Biaya Gaji & $544.320 .000,00$ \\
Biaya Bahan Habis Pakai Umum & $271.859 .372,00$ \\
Biaya Listrik & $76.049 .248,00$ \\
Biaya Air & $146.077 .244,00$ \\
Biaya Telepon & $29.136 .060,00$ \\
$\quad$ Biaya Gizi & $1.638 .611 .326,00$ \\
\hline Batch Related Activity Cost & \\
$\quad$ Biaya ATK & $27.369 .078,00$ \\
\hline Product Sustaining Activity Cost & \\
$\quad$ Biaya Diklat & $56.745 .000,00$ \\
\hline Facility Sustaining Activity Cost & \\
$9 \quad$ Biaya Linen & $398.442 .500,00$ \\
10 Biaya Penyusutan Gedung & $280.078 .551,00$ \\
11 Biaya Penyusutan Fasilitas & $468.304 .254,00$ \\
12 Biaya Pemeliharaan Gedung & $63.317 .739,00$ \\
13 Biaya Pemeliharaan Fasilitas & $72.369 .278,00$ \\
14 Biaya Kebersihan & $68.545 .690,00$ \\
\hline
\end{tabular}

Tabel 5. Kelompok Biaya Homogen dan Pemicu Biaya (dalam rupiah)

\begin{tabular}{lcr}
\hline \multicolumn{1}{c}{ Kelompok Biaya Homogen } & $\begin{array}{c}\text { Pemicu Biaya } \\
\text { (cost driver) }\end{array}$ & \multicolumn{1}{c}{ Jumlah (Rp) } \\
\hline Biaya Langsung: & & \\
Biaya Bahan Habis Pakai Umum & Jumlah Hari Rawat & $271.859 .372,00$ \\
Biaya Gizi & Inap Pasien & $\begin{array}{r}.638 .611 .326,00 \\
\text { Biaya Gaji }\end{array}$ \\
Jumlah Biaya Langsung & (hari) & $544.320 .000,00$ \\
\hline
\end{tabular}


Wiguna - Activity Based Costing System sebagai ...

\begin{tabular}{|c|c|c|}
\hline Kelompok Biaya Homogen & $\begin{array}{c}\text { Pemicu Biaya } \\
\text { (cost driver) }\end{array}$ & Jumlah (Rp) \\
\hline \multicolumn{3}{|l|}{ Biaya Tidak Langsung: } \\
\hline \multicolumn{3}{|l|}{ Cost Pool 1} \\
\hline Biaya ATK & Jumlah Pasien & $27.369 .078,00$ \\
\hline Biaya Diklat & (orang) & $56.745 .000,00$ \\
\hline Jumlah & & $84.114 .078,00$ \\
\hline \multicolumn{3}{|l|}{ Cost Pool 2} \\
\hline Biaya Air & Jumlah Hari Rawat & $146.077 .244,00$ \\
\hline Biaya Telepon & Inap Pasien & $29.136 .060,00$ \\
\hline Biaya Linen & (hari) & $398.442 .500,00$ \\
\hline Biaya Pemeliharaan Fasilitas & & $72.369 .278,00$ \\
\hline Biaya Penyusutan Fasilitas: & & $98.161 .100,00$ \\
\hline AC (VIP-A, VIP-B, VIP-C/Ut) & & $18.550 .000,00$ \\
\hline \multicolumn{3}{|l|}{ Bed (VIP-A, VIP-B, VIP-C/Ut, K-I, } \\
\hline K-II, K-III) & & $11.765 .000,00$ \\
\hline TV (VIP-A, VIP-B) & & $15.580 .000,00$ \\
\hline Kulkas (VIP-A, VIP-B) & & $16.705 .000,00$ \\
\hline Dispenser (VIP-A) & & $5.886 .000,00$ \\
\hline Kipas (VIP-C) & & $4.965 .500,00$ \\
\hline Sofa tamu (VIP-A, VIP-B) & & $5.375 .600,00$ \\
\hline \multicolumn{3}{|c|}{ Kursi (VIP-A, VIP-B, VIP-C/Ut, K-I } \\
\hline K-II, K-III) & & $10.564 .000,00$ \\
\hline \multicolumn{3}{|c|}{ Meja Pasien (VIP-A, VIP-B, VIP-C/Ut } \\
\hline K-I, K-II, K-III) & & $8.770 .000,00$ \\
\hline Jumlah & & $744.168 .182,00$ \\
\hline \multicolumn{3}{|l|}{ Cost Pool 3} \\
\hline Biaya Penyusutan Gedung & & $280.078 .551,00$ \\
\hline Biaya Pemeliharaan Gedung & Luas Lantai & $63.317 .739,00$ \\
\hline Biaya Kebersihan & & $68.545 .690,00$ \\
\hline Jumlah & & $441.914 .980,00$ \\
\hline \multicolumn{3}{|l|}{ Cost Pool 4} \\
\hline Biaya Listrik & KWH & 76.049.248,00 \\
\hline Jumlah Biaya Tidak Langsung & & $1.346 .264 .488,00$ \\
\hline
\end{tabular}

Tabel 6. Lama Hari Pasien Rawat Inap RSUD Kabupaten Buleleng 2016

\begin{tabular}{lcccccc}
\hline \multirow{2}{*}{ Bulan } & \multicolumn{7}{c}{ Kelas Perawatan } \\
\cline { 2 - 7 } Vanuari & VIP-A & VIP-B & VIP-C/Ut & K-I & K-II & K-III \\
\hline Februari & 84 & 127 & 138 & 128 & 117 & 558 \\
Maret & 55 & 101 & 147 & 142 & 203 & 577 \\
April & 107 & 95 & 105 & 212 & 249 & 582 \\
Mei & 92 & 102 & 191 & 140 & 321 & 540 \\
Juni & 104 & 93 & 129 & 123 & 188 & 657 \\
Juli & 94 & 129 & 190 & 251 & 218 & 409 \\
Agustus & 117 & 125 & 149 & 176 & 153 & 450 \\
September & 58 & 113 & 150 & 195 & 281 & 489 \\
Oktober & 88 & 90 & 194 & 277 & 265 & 440 \\
November & 93 & 110 & 79 & 178 & 280 & 468 \\
Desember & 115 & 110 & 97 & 167 & 169 & 545 \\
\hline Total & 1114 & 1320 & 1651 & 2125 & 2582 & 6242 \\
\hline
\end{tabular}

Sumber: Medical Record RSUD Kabupaten Buleleng 
Tabel 7. Jumlah Pasien Rawat Inap RSUD Kabupaten Buleleng 2016

\begin{tabular}{lc}
\hline Kelas Perawatan & Jumlah Pasien \\
\hline Mahotama (VIP-A) & 370 \\
Madyatama (VIP-B) & 577 \\
Utama (VIP-C) & 627 \\
Kelas I & 564 \\
Kelas II & 695 \\
Kelas III & 1775 \\
\hline Total & 4608 \\
\hline
\end{tabular}

Sumber: Medical Record RSUD Kabupaten Buleleng

Tabel 8. Luas Ruangan Rawat Inap RSUD Kabupaten Buleleng

\begin{tabular}{lc}
\hline Kelas Perawatan & Luas Ruangan $\left(\mathrm{m}^{2}\right)$ \\
\hline Mahotama (VIP-A) & 480 \\
Madyatama (VIP-B) & 320 \\
Utama (VIP-C) & 320 \\
Kelas I & 435 \\
Kelas II & 420 \\
Kelas III & 434 \\
\hline Total & 2409 \\
\hline
\end{tabular}

Sumber: Denah RSUD Kabupaten Buleleng

Tabel 9. Tarif Konsumsi RSUD Kabupaten Buleleng 2016

\begin{tabular}{lc}
\hline Kelas Perawatan & Tarif Makan (Rp) \\
\hline Mahotama (VIP-A) & 45.000 \\
Madyatama (VIP-B) & 40.000 \\
Utama (VIP-C) & 35.000 \\
Kelas I & 25.725 \\
Kelas II & 21.000 \\
Kelas III & 19.000 \\
\hline
\end{tabular}

Sumber: Struktur Biaya Ruangan RSUD Kabupaten Buleleng

Tabel 10 berikut menunjukkan perawatan rawat inap yang akan penggunaan tenaga listrik pada unit digunakan sebagai dasar rawat inap ini menunjukkan pembebanan biaya. konsumsi listrik pada tiap kelas

Tabel 10. Penggunaan Tenaga Listrik Unit Rawat Inap RSUD Kabupaten Buleleng 2016

\begin{tabular}{lc}
\hline Kelas Perawatan & KWH \\
\hline Mahotama (VIP-A) & $14.193,39$ \\
Madyatama (VIP-B) & $11.214,99$ \\
Utama (VIP-C) & $1.638,85$ \\
Kelas I & 609,55 \\
Kelas II & $1.098,65$ \\
Kelas III & $2.044,00$ \\
\hline Total & $30.779,43$ \\
\hline
\end{tabular}


Tabel 11. Kelompok Biaya (Cost Pool Rate) dan Penentuan Tarif/unit

\begin{tabular}{|c|c|c|c|}
\hline Kelompok Biaya & Pemicu Biaya & Jumlah (Rp) & $\begin{array}{l}\text { Tarif per unit } \\
(\mathrm{Rp})\end{array}$ \\
\hline $\begin{array}{l}\text { Biaya Langsung: } \\
\text { Biaya Bahan Habis Pakai } \\
\text { Umum } \\
\text { Biaya Gizi } \\
\text { Biaya Gaji }\end{array}$ & $\begin{array}{l}15.034 \\
\text { (hari rawat } \\
\text { inap) }\end{array}$ & $\begin{array}{r}271.859 .375,00 \\
1.638 .611 .326,00 \\
544.320 .000,00\end{array}$ & $\begin{array}{r}18.082,97 \\
\text { Sesuai tarif } \\
\text { konsumsi } \\
36.205,93 \\
\end{array}$ \\
\hline $\begin{array}{l}\text { Biaya Tidak Langsung : } \\
\text { Cost Pool } 1 \text { : } \\
\text { Biaya ATK } \\
\text { Biaya Diklat }\end{array}$ & $\begin{array}{l}4608 \\
\text { (orang) }\end{array}$ & $\begin{array}{l}27.369 .078,00 \\
56.745 .000,00\end{array}$ & $\begin{array}{r}5.939,47 \\
12.314,45\end{array}$ \\
\hline $\begin{array}{l}\text { Cost Pool 2: } \\
\text { Biaya Air } \\
\text { Biaya Telepon } \\
\text { Biaya Linen } \\
\text { Biaya } \quad \text { Pemeliharaan } \\
\text { Fasilitas }\end{array}$ & $\begin{array}{l}15.034 \\
\text { (hari rawat } \\
\text { inap) }\end{array}$ & $\begin{array}{r}146.077 .244,00 \\
29.136 .060,00 \\
398.442 .500,00 \\
72.369 .278,00\end{array}$ & $\begin{array}{r}9.716,46 \\
1.938,01 \\
26.502,76 \\
4.813,71\end{array}$ \\
\hline $\begin{array}{l}\text { Biaya Penyusutan Fasilitas } \\
\text { 1. AC (VIPA,VIPB,VIPC/Ut } \\
\text { 2. Bed } \\
\text { (VIPA,VIPB,VIPC/Ut, } \\
\text { KI,KII,KIII) } \\
\text { 3. TV (VIPA,VIPB) } \\
\text { 4. Kulkas (VIPA, VIPB) } \\
\text { 5. Dispenser (VIPA) } \\
\text { 6. Kipas (VIPC) } \\
\text { 7. Sofa tamu (VIPA,VIPB) } \\
\text { 8. Kursi (VIPA,VIPB, } \\
\text { VIPC/Ut,KI,KII,KIII) } \\
\text { 9. Meja pasien (VIPA, } \\
\text { VIPB, VIPC/Ut, } \\
\text { KI,KII,KIII) }\end{array}$ & $\begin{array}{c}2.434 \\
2.434 \\
1.114 \\
1.651 \\
2.434 \\
15.304\end{array}$ & $\begin{array}{r}98.161 .100,00 \\
18.550 .000,00 \\
11.765 .000,00 \\
\\
15.580 .000,00 \\
16.705 .000,00 \\
5.886 .000,00 \\
4.965 .500,00 \\
5.375 .600,00 \\
10.564 .000,00\end{array}$ & $\begin{array}{r}9.893,33 \\
756,66 \\
\\
6.400,99 \\
6.863,19 \\
5.283,66 \\
3.007,57 \\
2.208,54 \\
690,28\end{array}$ \\
\hline $\begin{array}{l}\text { Cost Pool } 3 \text { : } \\
\text { Biaya Penyusutan Gedung } \\
\text { Biaya Pemeliharaan Gedung } \\
\text { Biaya Kebersihan }\end{array}$ & $\begin{array}{c}2409 \\
\left(\mathrm{~m}^{2}\right)\end{array}$ & $\begin{array}{r}280.078 .551,00 \\
63.317 .739,00 \\
68.545 .690,00 \\
441.914 .980,00\end{array}$ & $\begin{array}{r}116.263,41 \\
26.283,82 \\
28.454,00 \\
\end{array}$ \\
\hline $\begin{array}{l}\text { Cost Pool 4: } \\
\text { Biaya Listrik }\end{array}$ & $\begin{array}{c}30.779,43 \\
(\mathrm{KWH})\end{array}$ & $\begin{array}{l}76.049 .248,00 \\
76.049 .248,00\end{array}$ & $2.470,78$ \\
\hline $\begin{array}{lll}\text { Jumlah } & \text { Biaya } & \text { Tidak } \\
\text { Langsung } & & \\
\end{array}$ & & $1.346 .264 .488,00$ & \\
\hline
\end{tabular}


Jurnal Ilmiah Akuntansi • Vol. 2, No. 2, hal: 148-172 • Desember 2017

Perhitungan tarif rawat inap adalah sebagai berikut:

pada RSUD Kabupaten Buleleng

Tabel 12 Tarif Jasa Rawat Inap Kelas Mahotama (VIP-A)

\begin{tabular}{|c|c|c|c|}
\hline Kelompok Biaya & $\begin{array}{l}\text { Tarif Pemicu } \\
\text { Biaya }\end{array}$ & Pemicu Biaya & Total \\
\hline \multicolumn{4}{|l|}{ Biaya Langsung: } \\
\hline $\begin{array}{l}\text { Biaya Bahan Habis Pakai } \\
\text { Umum }\end{array}$ & $18.082,97$ & 1114 & $20.144 .428,58$ \\
\hline Biaya Gizi & $45.000,00$ & 1114 & $50.130 .000,00$ \\
\hline Biaya Gaji & $36.205,93$ & 1114 & 40.333.406,02 \\
\hline Jumlah Biaya Langsung & & & $110.607 .834,6$ \\
\hline \multicolumn{4}{|l|}{ Biaya Tidak Langsung: } \\
\hline \multicolumn{4}{|l|}{ Cost Pool 1} \\
\hline Biaya ATK & $5.939,47$ & 370 & $2.197 .603,9$ \\
\hline Biaya Diklat & $12.314,45$ & 370 & 4.556 .346 .5 \\
\hline Jumlah & & & $6.753 .950,4$ \\
\hline \multicolumn{4}{|l|}{ Cost Pool 2} \\
\hline Biaya Air & $9.716,46$ & 1114 & $10.842 .136,44$ \\
\hline Biaya Telepon & $1.938,01$ & 1114 & $2.158 .943,14$ \\
\hline Biaya Linen & $26.502,76$ & 1114 & $29.524 .074,64$ \\
\hline Biaya Pemeliharaan Fasilitas & $4.813,71$ & 1114 & $5.362 .472,94$ \\
\hline Jumlah & & & $47.887 .672,16$ \\
\hline \multicolumn{4}{|l|}{ Biaya Penyusutan Fasilitas } \\
\hline 1. AC & $9.893,33$ & 1114 & $11.021 .169,62$ \\
\hline 2. Bed & 756,66 & 1114 & $842.919,24$ \\
\hline 3. TV & $6.400,99$ & 1114 & $7.130 .702,86$ \\
\hline 4. Kulkas & $6.863,19$ & 1114 & $7.645 .593,66$ \\
\hline 5. Dispenser & $5.283,66$ & 1114 & $5.885 .997,24$ \\
\hline 6. Sofa tamu & $2.208,54$ & 1114 & $2.460 .313,56$ \\
\hline 7. Kursi & 690,28 & 1114 & $768.971,92$ \\
\hline 8. Meja pasien & 573,05 & 1114 & 638.377 .7 \\
\hline Jumlah & & & $36.394 .045,8$ \\
\hline \multicolumn{4}{|l|}{ Cost Pool 3} \\
\hline Biaya Penyusutan Gedung & $116.263,41$ & 480 & $55.793 .476,8$ \\
\hline Biaya Pemeliharaan Gedung & $26.283,82$ & 480 & 12.616.233,6 \\
\hline Biaya Kebersihan & $28.454,00$ & 480 & $13.657 .920,00$ \\
\hline Jumlah & & & $82.067 .630,4$ \\
\hline \multicolumn{4}{|l|}{ Cost Pool 4} \\
\hline Biaya Listrik & $2.470,78$ & $14.193,39$ & $35.068 .744,14$ \\
\hline Jumlah Biaya Tidak Langsung & & & $208.172 .042,9$ \\
\hline Total Biaya & & & $318.779 .877,5$ \\
\hline Jumlah Hari Pakai & & & 1114 \\
\hline Biaya Pokok Per Kamar & & & $286.157,88$ \\
\hline Persentase Laba 15\% & & & $42.923,68$ \\
\hline
\end{tabular}


Wiguna - Activity Based Costing System sebagai ...

\begin{tabular}{lccc}
\hline \multicolumn{1}{c}{ Kelompok Biaya } & $\begin{array}{c}\text { Tarif Pemicu } \\
\text { Biaya }\end{array}$ & Pemicu Biaya & Total \\
\hline Tarif Rawat Inap & & & $329.081,56$ \\
\hline Sumber: Data Diolah & & &
\end{tabular}

Tabel 13 Tarif Jasa Rawat Inap Kelas Madyatama (VIP-B)

\begin{tabular}{|c|c|c|c|}
\hline Kelompok Biaya & $\begin{array}{l}\text { Tarif Pemicu } \\
\text { Biaya }\end{array}$ & Pemicu Biaya & Total \\
\hline \multicolumn{4}{|l|}{ Biaya Langsung } \\
\hline $\begin{array}{l}\text { Biaya Bahan Habis Pakai } \\
\text { Umum }\end{array}$ & $18.082,97$ & 1320 & $23.869 .520,4$ \\
\hline Biaya Gizi & $40.000,00$ & 1320 & $52.800 .000,0$ \\
\hline Biaya Gaji & $36.205,93$ & 1320 & $47.791 .827,6$ \\
\hline Jumlah Biaya Langsung & & & 124.461 .348 \\
\hline \multicolumn{4}{|l|}{ Biaya Tidak Langsung } \\
\hline \multicolumn{4}{|l|}{ Cost Pool 1} \\
\hline Biaya ATK & $5.939,47$ & 577 & $3.427 .074,19$ \\
\hline Biaya Diklat & $12.314,45$ & 577 & $7.105 .437,65$ \\
\hline Jumlah & & & $10.532 .511,84$ \\
\hline \multicolumn{4}{|l|}{ Cost Pool 2} \\
\hline Biaya Air & $9.716,46$ & 1320 & $12.825 .727,2$ \\
\hline Biaya Telepon & $1.938,01$ & 1320 & $2.558 .173,2$ \\
\hline Biaya Linen & $26.502,76$ & 1320 & $34.983 .643,2$ \\
\hline Biaya Pemeliharaan Fasilitas & $4.813,71$ & 1320 & $6.354 .097,2$ \\
\hline Jumlah & & & $56.721 .640,8$ \\
\hline \multicolumn{4}{|l|}{ Biaya Penyusutan Fasilitas } \\
\hline 1. AC & $9.893,33$ & 1320 & 13.059.195,6 \\
\hline 2. Bed & 756,66 & 1320 & $998.791,2$ \\
\hline 3. TV & $6.400,99$ & 1320 & 8.449.306.8 \\
\hline 4. Kulkas & $6.863,19$ & 1320 & $9.059 .410,8$ \\
\hline 5. Sofa tamu & $2.208,54$ & 1320 & 2.915.272,8 \\
\hline 6. Kursi & 690,28 & 1320 & $911.169,6$ \\
\hline 7. Meja pasien & 573,05 & 1320 & 756.426 \\
\hline Jumlah & & & $36.146 .572,8$ \\
\hline \multicolumn{4}{|l|}{ Cost Pool 3} \\
\hline Biaya Penyusutan Gedung & $116.263,41$ & 320 & $37.195 .651,2$ \\
\hline Biaya Pemeliharaan Gedung & $26.283,82$ & 320 & $8.410 .822,4$ \\
\hline Biaya Kebersihan & $28.454,00$ & 320 & 9.105 .280 \\
\hline Jumlah & & & $54.711 .753,6$ \\
\hline \multicolumn{4}{|l|}{ Cost Pool 4: } \\
\hline Biaya Listrik & $2.470,78$ & $11.214,99$ & 27.709.772,99 \\
\hline Jumlah Biaya Tidak Langsung & & & 185.822 .252 \\
\hline Total Biaya & & & 310.283 .600 \\
\hline Jumlah Hari Pakai & & & 1320 \\
\hline Biaya Pokok Per Kamar & & & $235.063,33$ \\
\hline Persentase Laba 12\% & & & $28.207,60$ \\
\hline
\end{tabular}




\begin{tabular}{|c|c|c|c|}
\hline Kelompok Biaya & $\begin{array}{l}\text { Tarif Pemicu } \\
\text { Biaya }\end{array}$ & Pemicu Biaya & Total \\
\hline Tarif Rawat Inap & & & $263.270,93$ \\
\hline \multicolumn{4}{|l|}{ Sumber: Data Diolah } \\
\hline \multicolumn{4}{|c|}{ Tabel 14 Tarif Jasa Rawat Inap Kelas Utama (VIP-C) } \\
\hline Kelompok Biaya & $\begin{array}{l}\text { Tarif Pemicu } \\
\text { Biaya }\end{array}$ & Pemicu Biaya & Total \\
\hline \multicolumn{4}{|l|}{ Biaya Langsung } \\
\hline $\begin{array}{l}\text { Biaya Bahan Habis } \text { Pakai } \\
\text { Umum }\end{array}$ & $18.082,97$ & 1651 & $29.854 .983,47$ \\
\hline Biaya Gizi & $35.000,00$ & 1651 & 57.785 .000 \\
\hline Biaya Gaji & $36.205,93$ & 1651 & $59.775 .990,43$ \\
\hline Jumlah Biaya Langsung & & & $147.415 .973,9$ \\
\hline \multicolumn{4}{|l|}{ Biaya Tidak Langsung } \\
\hline \multicolumn{4}{|l|}{ Cost Pool 1} \\
\hline Biaya ATK & $5.939,47$ & 627 & $3.724 .047,69$ \\
\hline Biaya Diklat & $12.314,45$ & 627 & $7.721 .160,15$ \\
\hline Jumlah & & & $11.445 .207,84$ \\
\hline \multicolumn{4}{|l|}{ Cost Pool 2} \\
\hline Biaya Air & $9.716,46$ & 1651 & $16.041 .875,46$ \\
\hline Biaya Telepon & $1.938,01$ & 1651 & $3.197 .716,5$ \\
\hline Biaya Linen & $26.502,76$ & 1651 & $43.756 .056,76$ \\
\hline Biaya Pemeliharaan Fasilitas & $4.813,71$ & 1651 & $7.947 .435,21$ \\
\hline Jumlah & & & $70.943 .083,93$ \\
\hline \multicolumn{4}{|l|}{ Biaya Penyusutan Fasilitas } \\
\hline 1. $\mathrm{AC}$ & $9.893,33$ & 1651 & $16.333 .887,83$ \\
\hline 2. Bed & 756,66 & 1651 & $1.249 .245,66$ \\
\hline 3. Kursi & 690,28 & 1651 & $1.139 .652,28$ \\
\hline 4. Meja pasien & 573,05 & 1651 & 946.105 .55 \\
\hline 5. Kipas & $3.007,57$ & 1651 & $4.965 .498,07$ \\
\hline Jumlah & & & $24.634 .389,39$ \\
\hline \multicolumn{4}{|l|}{ Cost Pool 3} \\
\hline Biaya Penyusutan Gedung & $116.263,41$ & 320 & $37.204 .291,2$ \\
\hline Biaya Pemeliharaan Gedung & $26.283,82$ & 320 & $8.410 .822,4$ \\
\hline Biaya Kebersihan & $28.454,00$ & 320 & 9.105 .280 \\
\hline Jumlah & & & $54.720 .393,6$ \\
\hline \multicolumn{4}{|l|}{ Cost Pool 4} \\
\hline Biaya Listrik & $2.470,78$ & $1.638,85$ & $4.049 .237,80$ \\
\hline Jumlah Biaya Tidak Langsung & & & $165.802 .312,6$ \\
\hline Total Biaya & & & $313.218 .286,5$ \\
\hline Jumlah Hari Pakai & & & 1651 \\
\hline Biaya Pokok Per Kamar & & & $189.714,27$ \\
\hline Persentase Laba $12 \%$ & & & $22.765,71$ \\
\hline Tarif Rawat Inap & & & $212.479,98$ \\
\hline
\end{tabular}


Tabel 15 Tarif Jasa Rawat Inap Kelas I

\begin{tabular}{|c|c|c|c|}
\hline Kelompok Biaya & $\begin{array}{l}\text { Tarif Pemicu } \\
\text { Biaya }\end{array}$ & Pemicu Biaya & Total \\
\hline \multicolumn{4}{|l|}{ Biaya Langsung } \\
\hline $\begin{array}{l}\text { Biaya Bahan Habis Pakai } \\
\text { Umum }\end{array}$ & $18.082,97$ & 2125 & $38.426 .311,25$ \\
\hline Biaya Gizi & $25.725,00$ & 2125 & $54.665 .625,00$ \\
\hline Biaya Gaji & $36.205,93$ & 2125 & $76.937 .601,25$ \\
\hline Jumlah Biaya Langsung & & & $170.029 .537,5$ \\
\hline \multicolumn{4}{|l|}{ Biaya Tidak Langsung } \\
\hline \multicolumn{4}{|l|}{ Cost Pool 1} \\
\hline Biaya ATK & $5.939,47$ & 564 & $3.349 .861,08$ \\
\hline Biaya Diklat & $12.314,45$ & 564 & $6.945 .349,8$ \\
\hline Jumlah & & & $10.295 .210,88$ \\
\hline \multicolumn{4}{|l|}{ Cost Pool 2} \\
\hline Biaya Air & $9.716,46$ & 2125 & $20.647 .477,5$ \\
\hline Biaya Telepon & $1.938,01$ & 2125 & $4.118 .271,25$ \\
\hline Biaya Linen & $26.502,76$ & 2125 & $56.318 .365,00$ \\
\hline Biaya Pemeliharaan Fasilitas & $4.813,71$ & 2125 & $10.229 .133,75$ \\
\hline Jumlah & & & $91.313 .247,5$ \\
\hline \multicolumn{4}{|l|}{ Biaya Penyusutan Fasilitas: } \\
\hline 1. Bed & 756,66 & 2125 & $1.607 .902,5$ \\
\hline 2. Kursi & 690,28 & 2125 & 1.466 .845 \\
\hline 3. Meja pasien & 573,05 & 2125 & $1.217 .731,25$ \\
\hline Jumlah & & & $4.272 .478,75$ \\
\hline \multicolumn{4}{|l|}{ Cost Pool 3} \\
\hline Biaya Penyusutan Gedung & $116.263,41$ & 435 & $50.574 .583,35$ \\
\hline Biaya Pemeliharaan Gedung & $26.283,82$ & 435 & $11.433 .461,7$ \\
\hline Biaya Kebersihan & $28.454,00$ & 435 & 12.377 .490 \\
\hline Jumlah & & & $74.385 .535,05$ \\
\hline \multicolumn{4}{|l|}{ Cost Pool 4} \\
\hline Biaya Listrik & $2.470,78$ & 609.55 & $1.506 .063,94$ \\
\hline Jumlah Biaya Tidak Langsung & & & $181.772 .536,1$ \\
\hline Total Biaya & & & $351.802 .073,6$ \\
\hline Jumlah Hari Pakai & & & 2125 \\
\hline Biaya Pokok Per Kamar & & & $165.553,92$ \\
\hline Persentase Laba 10\% & & & $16.555,39$ \\
\hline Tarif Rawat Inap & & & $182.109,31$ \\
\hline
\end{tabular}


Tabel 16. Tarif Jasa Rawat Inap Kelas II

\begin{tabular}{|c|c|c|c|}
\hline Kelompok Biaya & $\begin{array}{l}\text { Tarif Pemicu } \\
\text { Biaya }\end{array}$ & Pemicu Biaya & Total \\
\hline \multicolumn{4}{|l|}{ Biaya Langsung } \\
\hline $\begin{array}{l}\text { Biaya Bahan Habis Pakai } \\
\text { Umum }\end{array}$ & $18.082,97$ & 2582 & $46.690 .228,54$ \\
\hline Biaya Gizi & $21.000,00$ & 2582 & 54.222 .000 \\
\hline Biaya Gaji & $36.205,93$ & 2582 & $93.483 .711,26$ \\
\hline Jumlah Biaya Langsung & & & $194.395 .939,8$ \\
\hline \multicolumn{4}{|l|}{ Biaya Tidak Langsung } \\
\hline \multicolumn{4}{|l|}{ Cost Pool 1} \\
\hline Biaya ATK & $5.939,47$ & 695 & 4.127.931,65 \\
\hline Biaya Diklat & $12.314,45$ & 695 & $8.558 .542,75$ \\
\hline Jumlah & & & $12.686 .474,4$ \\
\hline \multicolumn{4}{|l|}{ Cost Pool 2} \\
\hline Biaya Air & $9.716,46$ & 2582 & $25.087 .899,72$ \\
\hline Biaya Telepon & $1.938,01$ & 2582 & $5.003 .941,82$ \\
\hline Biaya Linen & $26.502,76$ & 2582 & $68.430 .126,32$ \\
\hline Biaya Pemeliharaan Fasilitas & $4.813,71$ & 2582 & $12.428 .999,22$ \\
\hline Jumlah & & & $110.950 .967,1$ \\
\hline \multicolumn{4}{|l|}{ Biaya Penyusutan Fasilitas : } \\
\hline 1. Bed & 756,66 & 2582 & $1.953 .696,12$ \\
\hline 2. Kursi & 690,28 & 2582 & $1.782 .302,96$ \\
\hline 3. Meja pasien & 573,05 & 2582 & $1.479 .615,1$ \\
\hline Jumlah & & & $5.215 .614,18$ \\
\hline \multicolumn{4}{|l|}{ Cost Pool 3} \\
\hline Biaya Penyusutan Gedung & $116.263,41$ & 420 & $48.830 .632,2$ \\
\hline Biaya Pemeliharaan Gedung & $26.283,82$ & 420 & $11.039 .204,4$ \\
\hline Biaya Kebersihan & $28.454,00$ & 420 & 11.950 .680 \\
\hline Jumlah & & & $71.820 .516,6$ \\
\hline \multicolumn{4}{|l|}{ Cost Pool 4} \\
\hline Biaya Listrik & $2.470,78$ & $1.098,65$ & $2.714 .522,45$ \\
\hline Jumlah Biaya Tidak Langsung & & & $203.388 .094,7$ \\
\hline Total Biaya & & & $397.784 .034,5$ \\
\hline Jumlah Hari Pakai & & & 2582 \\
\hline Biaya Pokok Per Kamar & & & $154.060,43$ \\
\hline Persentase Laba 10\% & & & $15.406,04$ \\
\hline Tarif Rawat Inap & & & $169.466,47$ \\
\hline
\end{tabular}


Tabel 17. Tarif Jasa Rawat Inap Kelas III

\begin{tabular}{|c|c|c|c|}
\hline Kelompok Biaya & $\begin{array}{l}\text { Tarif Pemicu } \\
\text { Biaya }\end{array}$ & Pemicu Biaya & Total \\
\hline \multicolumn{4}{|l|}{ Biaya Langsung } \\
\hline $\begin{array}{l}\text { Biaya Bahan Habis Pakai } \\
\text { Umum }\end{array}$ & $18.082,97$ & 6242 & $112.873 .898,7$ \\
\hline Biaya Gizi & $19.000,00$ & 6242 & 118.598 .000 \\
\hline Biaya Gaji & $36.205,93$ & 6242 & $225.997 .415,1$ \\
\hline Jumlah Biaya Langsung & & & $457.469 .313,8$ \\
\hline \multicolumn{4}{|l|}{ Biaya Tidak Langsung } \\
\hline \multicolumn{4}{|l|}{ Cost Pool 1} \\
\hline Biaya ATK & $5.939,47$ & 1775 & $10.542 .559,25$ \\
\hline Biaya Diklat & $12.314,45$ & 1775 & $21.858 .148,75$ \\
\hline Jumlah & & & 32.400 .708 \\
\hline \multicolumn{4}{|l|}{ Cost Pool 2} \\
\hline Biaya Air & $9.716,46$ & 6242 & $60.650 .143,32$ \\
\hline Biaya Telepon & $1.938,01$ & 6242 & $12.097 .058,47$ \\
\hline Biaya Linen & $26.502,76$ & 6242 & $165.430 .227,9$ \\
\hline Biaya Pemeliharaan Fasilitas & $4.813,71$ & 6242 & $30.047 .177,82$ \\
\hline Jumlah & & & $268.224 .607,5$ \\
\hline \multicolumn{4}{|l|}{ Biaya Penyusutan Fasilitas } \\
\hline 1. Bed & 756,66 & 6242 & 4.723.071,72 \\
\hline 2. Kursi & 690,28 & 6242 & 4.308 .727 .76 \\
\hline 3. Meja pasien & 573,05 & 6242 & 3.576.978.1 \\
\hline Jumlah & & & $12.608 .777,58$ \\
\hline \multicolumn{4}{|l|}{ Cost Pool 3} \\
\hline Biaya Penyusutan Gedung & $116.263,41$ & 434 & $50.458 .319,94$ \\
\hline Biaya Pemeliharaan Gedung & $26.283,82$ & 434 & $11.407 .177,88$ \\
\hline Biaya Kebersihan & $28.454,00$ & 434 & 12.349 .036 \\
\hline Jumlah & & & $74.214 .533,82$ \\
\hline \multicolumn{4}{|l|}{ Cost Pool 4} \\
\hline Biaya Listrik & $2.470,78$ & $2.044,00$ & $5.050 .274,32$ \\
\hline Jumlah Biaya Tidak Langsung & & & $392.498 .901,2$ \\
\hline Total Biaya & & & 849.968 .215 \\
\hline Jumlah Hari Pakai & & & 6242 \\
\hline Biaya Pokok Per Kamar & & & $136.169,21$ \\
\hline Persentase Laba 5\% & & & $6.808,46$ \\
\hline Tarif Rawat Inap & & & $142.977,67$ \\
\hline
\end{tabular}

Dari hasil perhitungan diatas maka diketahui tarif jasa rawat inap RSUD Kabupaten Buleleng dengan menggunakan metode $\mathrm{ABC}$ system sebagai berikut: 
Tabel 18. Tarif Jasa Rawat Inap RSUD Kabupaten Buleleng dengan Metode $A B C$ (dalam rupiah)

\begin{tabular}{lr}
\hline Kelas Perawatan & Tarif Rawat Inap $\left(\mathrm{X}_{2}\right)$ \\
\hline Kelas Mahotama (VIP A) & $392.081,56$ \\
Kelas Madyatama (VIP B) & $263.270,93$ \\
Kelas Utama (VIP C) & $212.479,98$ \\
Kelas I & $182.109,31$ \\
Kelas II & $169.466,47$ \\
Kelas III & $142.977,67$ \\
\hline
\end{tabular}

Sumber: Data Diolah

Tabel 19. Tarif Jasa Rawat Inap dan Pendapatan Rawat Inap RSUD

\begin{tabular}{lcccc}
\hline \multicolumn{1}{c}{ Kelas Perawatan } & $\begin{array}{c}\text { Tarif } \\
\text { Tradisional }\end{array}$ & Tarif ABC & $\begin{array}{c}\text { Pendapatan } \\
\text { Tradisional }\end{array}$ & $\begin{array}{c}\text { Pendapatan } \\
\text { ABC }\end{array}$ \\
\hline $\begin{array}{l}\text { Kelas Mahotama } \\
\text { (VIP-A) }\end{array}$ & $173.000,00$ & $329.081,56$ & $192.722 .000,00$ & $336.596 .857,80$ \\
Kelas Madyatama & $162.000,00$ & $263.270,93$ & $213.840 .000,00$ & $347.517 .627,60$ \\
(VIP-B) & $151.000,00$ & $212.479,98$ & $249.301 .000,00$ & $350.804 .447,00$ \\
Kelas Utama (VIP-C) & $65.000,00$ & $182.109,31$ & $138.125 .000,00$ & $386.982 .283,80$ \\
Kelas I & $48.000,00$ & $169.466,47$ & $123.936 .000,00$ & $437.562 .425,50$ \\
Kelas II & $30.000,00$ & $142.977,67$ & $187.260 .000,00$ & $892.466 .616,10$ \\
Kelas III & tal
\end{tabular}

Sumber: Perhitungan tarif jasa rawat inap dengan menggunakan metode $A B C$ sistem dan perhitungan pendapatan tarif jasa rawat inap dengan metode $A B C$ sistem.

Tabel 19 diatas menunjukkan data-data penelitian yang akan di uji. Tarif dengan metode tradisional adalah data yang diperoleh dari rumah sakit, kemudian dengan dasar biaya yang sama dihitung tarif rawat inap dengan menggunakan metode ABC. Setelah diketahui besar masingmasing tarif kemudian dapat dihitung masing-masing pendapatan rawat inapnya dengan cara mengalikan tarif dengan jumlah rawat inap pasien. Dari data-data diatas akan diuji bagaimana perbandingan antara tarif rawat inap dengan metode tradisional dan metode $A B C$ serta pengaruhnya terhadap pendapatan.

Tabel 20 berikut menunjukkan semua data penelitian berdistribusi normal. Hal tersebut dibuktikan dengan nilai Asymp.Sig. (2-tailed) masing-masing data penelitian $>0,05$. Demikian pula, berdasarkan hasil analisis uji t dua sampel (Paired Samples Test) pada Tabel 21 dapat diketahui bahwa nilai $t$ hitung sebesar 8,901 dan Nilai Sig (2-tailed) menunjukkan hasil $<0,05$. Dengan taraf kesalahan 0,05 dan $\mathrm{dk}=5$, maka diketahui $\mathrm{t}$ tabel adalah sebesar 2.015. Karena harga $\mathrm{t}$ hitung $>$ dari 
harga $t$ tabel dan nilai Sig (2-tailed) < 0,05 .

Tabel 20

Uji Kolmogorov-Smirnov

One-Sample Kolmogorov-Smirnov Test

\begin{tabular}{llrrrr}
\hline & & $\begin{array}{c}\text { Tarif } \\
\text { Tradisional }\end{array}$ & Tarif ABC & $\begin{array}{c}\text { Pendapatan } \\
\text { Tradisional }\end{array}$ & $\begin{array}{c}\text { Pendapatan } \\
\text { ABC }\end{array}$ \\
\hline $\mathrm{N}$ & & 6 & 6 & 6 & 6 \\
Normal & Mean & 104833.33 & 216564.320 & $1.8420 \mathrm{E} 8$ & $4.637 \mathrm{E} 8$ \\
Parametersa,b & & 33 & 0 & & \\
& Std. & 63973.171 & 68816.6677 & 46804515.0884 & $2.1264 \mathrm{E} 8$ \\
& Deviation & 46 & 4 & 7 & \\
Most Extreme & Absolute & .265 & .192 & .193 & .382 \\
Differences & Positive & .233 & .192 & .171 & .382 \\
& Negative & -.265 & -.142 & -.193 & -.292 \\
& .648 & .470 & .472 & .936 \\
Kolmogorov-Smirnov Z & & & & .979 & .345 \\
Asymp. Sig. (2-tailed) & .794 & .980 & & \\
\hline \multicolumn{2}{l}{}
\end{tabular}

Tabel 21

Uji t Dua Sampel (Paired Samples Test)

\begin{tabular}{|c|c|c|c|c|c|c|c|c|}
\hline & \multicolumn{5}{|c|}{ Paired Differences } & \multirow{3}{*}{$\mathrm{t}$} & \multirow{3}{*}{$\mathrm{df}$} & \\
\hline & \multirow[t]{2}{*}{ Mean } & \multirow[t]{2}{*}{$\begin{array}{c}\text { Std. } \\
\text { Deviation }\end{array}$} & \multirow[t]{2}{*}{$\begin{array}{l}\text { Std. Error } \\
\text { Mean }\end{array}$} & \multicolumn{2}{|c|}{$\begin{array}{c}\text { 95\% Confidence } \\
\text { Interval of the } \\
\text { Difference }\end{array}$} & & & $\begin{array}{l}\text { sig. } \\
(2- \\
\text { taile }\end{array}$ \\
\hline & & & & Lower & Upper & & & \\
\hline Pair 1 Tarif & 111730 & 30746.73 & 12552.30 & 79464.26 & 143997. & 8.9 & 5 & .00 \\
\hline $\begin{array}{l}\text { ABC- Tarif } \\
\text { Tradisional }\end{array}$ & .98667 & 976 & 394 & 216 & 71118 & 01 & & 0 \\
\hline
\end{tabular}

Di sisi lain, berdasarkan pedoman interpretasi koefisien korelasi sebesar 0,689 menunjukkan adanya korelasi cukup kuat dan positif. Pada tabel uji statistik diatas dapat diketahui pula nilai koefisien determinasi (R Square) adalah sebesar 0,474. Nilai koefisien determinasi tersebut menunjukkan bahwa tarif rawat inap dengan metode tradisional berpengaruh terhadap pendapatan rawat inap rumah sakit sebesar 47,4\%. Terakhir, berdasarkan pedoman interpretasi koefisien korelasi sebesar 0,595 menunjukkan adanya korelasi cukup kuat dan positif. Pada tabel uji statistik diatas dapat diketahui pula hasil koefisien determinasi (R Square) adalah sebesar 0,355. Nilai koefisien determinasi 
tersebut menunjukkan bahwa tarif rawat inap dengan metode tradisional berpengaruh terhadap pendapatan rawat inap rumah sakit sebesar $35,5 \%$.

Tabel 22

Uji Koefisien Korelasi dan Koefisien Determinasi (Metode Tradisional) Model Summary

\begin{tabular}{lrrrr}
\hline Model & $\mathrm{R}$ & $R$ Square & Adjusted R Square & $\begin{array}{c}\text { Std. Error of the } \\
\text { Estimate }\end{array}$ \\
\hline 1 & $.689 \mathrm{a}$ & .474 & .343 & 37935918.02016 \\
\hline
\end{tabular}

a. Predictors: (Constant), Tarif Tradisional

Tabel 23

Uji Koefisien Korelasi dan Koefisien Determinasi (Metode $A B C$ )

\begin{tabular}{rrrrr}
\hline Model & $\mathrm{R}$ & $R$ Square & Adjusted $R$ Square & $\begin{array}{c}\text { Std. Error of the } \\
\text { Estimate }\end{array}$ \\
\hline 1 & $.595^{\mathrm{a}}$ & .355 & .193 & $1.9100 \mathrm{E} 8$ \\
\hline
\end{tabular}

a. Predictors: (Constant), Tarif ABC

\section{Pembahasan}

Perbandingan Penetapan Tarif Jasa Rawat Inap Rumah Sakit dengan Metode Tradisional dan Metode ABC

Berdasarkan tabel 24 dapat diamati bahwa terdapat selisih antara tarif rawat inap dengan metode tradisional dan metode ABC. Selisih tersebut diakibatkan karena adanya perbedaan dalam penggunaan pemicu biaya (cost driver). Pada metode $\mathrm{ABC}$ pembebanan biaya menggunakan berbagai macam pemicu biaya sedangkan penentuan tarif dengan menggunakan metode tradisional pembebanan biaya langsung dan biaya tidak langsung hanya dibebankan pada satu pemicu biaya saja yaitu berdasarkan jumlah hari rawat inap pasien.

Hasil pengujian menunjukkan bahwa perbedaan antara kedua tarif yang dihasilkan kedua metode tersebut memiliki perbedaan yang signifikan karena selisih yang dihasilkan kedua metode tersebut cukup besar. Hasil penelitian ini sejalan dengan hasil penelitian Yulianti (2011) dan Amirah Said Bhaasen (2011) yang hasil penelitiannya juga menyatakan bahwa adanya perbedaan besar tarif yang dihasilkan perhitungan tarif jasa rawat inap rumah sakit dengan menggunakan metode tradisional dan metode ABC. 
Tabel 24

Tarif Rawat Inap Metode Tradisional dan Metode $A B C$

\begin{tabular}{lccc}
\hline \multicolumn{1}{c}{ Kelas Perawatan } & $\begin{array}{c}\text { Tarif Tradisional } \\
\left(\mathrm{X}_{1}\right)\end{array}$ & $\begin{array}{c}\text { Tarif } A B C \\
\left(\mathrm{X}_{2}\right)\end{array}$ & Selisih \\
\hline Kelas Mahotama (VIP-A) & $173.000,00$ & $329.081,56$ & $156.081,56$ \\
Kelas Madyatama (VIP-B) & $162.000,00$ & $263.270,93$ & $101.270,93$ \\
Kelas Utama (VIP-C) & $151.000,00$ & $212.479,98$ & $61.479,98$ \\
Kelas I & $65.000,00$ & $182.109,31$ & $117.109,31$ \\
Kelas II & $48.000,00$ & $169.466,47$ & $121.466,47$ \\
Kelas III & $30.000,00$ & $142.977,67$ & $112.977,67$ \\
\hline
\end{tabular}

\section{KESIMPULAN, IMPLIKASI DAN KETERBATASAN PENELITIAN}

Penetapan tarif jasa rawat inap rumah sakit dengan menggunakan metode tradisional dan metode $\mathrm{ABC}$ menghasilkan besar tarif yang berbeda. Perbedaan ini diakibatkan karena pembebanan biaya dengan metode ABC menggunakan pemicu biaya yang lebih banyak dibandingkan dengan metode tradisional. Penerapan tarif rawat inap dengan metode tradisional dan metode ABC memiliki hubungan cukup kuat dan positif terhadap pendapatan rawat inap. Hubungan yang cukup kuat dan positif ini menunjukkan bahwa apabila tarif rawat inap mengalami kenaikan atau penurunan maka pendapatan rawat inap rumah sakit juga akan mengalami kenaikan atau penurunan. Dengan menggunakan metode ABC system akan memaksimalkan pendapatan rawat inap RSUD karena dilakukan dengan pembebanan biaya yang cukup akurat.

Manajemen rumah sakit sebaiknya mulai mempertimbangan bagaimana perhitungan penentuan tarif jasa rawat inap dengan menggunakan metode ABC karena perhitungan tarif rawat inap dengan menggunakan metode ABC menggunakan pemicu biaya (Cost Driver) yang lebih banyak dari pada metode tradisional yang hanya menggunakan jumlah hari rawat inap pasien sehingga pembebanan biaya akan lebih akurat. Namun untuk penentuan pemicu biaya (Cost Driver) dalam metode $\mathrm{ABC}$ harus dilakukan melalui analisa yang mendalam agar terdapat kesesuaian antara konsumsi aktivitas yang diterangkan oleh pemicu biaya (Cost driver) yang dipilih dengan konsumsi aktivitas sesungguhnya.

Berdasarkan hasil pengujian meunjukkan bahwa penetapan tarif jasa rawat inap rumah sakit dengan 
menggunakan metode $\mathrm{ABC}$ system berpengaruh terhadap pendapatan rawat inap rumah sakit. Metode ini memiliki hubungan yang cukup kuat dan positif terhadap pendapatan rawat inap rumah sakit. Hubungan yang cukup kuat dan positif antara tarif rawat inap dengan metode $\mathrm{ABC}$ terhadap pendapatan rawat inap ini menunjukkan bahwa apabila tarif rawat inap mengalami kenaikan atau penurunan maka pendapatan rawat inap rumah sakit juga akan mengalami kenaikan atau penurunan. Hasil penelitian ini sejalan dengan hasil hasil penelitian Amirah Said Bhaasen (2011) yang menyatakan penetapan tarif rawat inap dengan $\mathrm{ABC}$ berpengaruh terhadap pendapatan rawat inap rumah sakit.

Hal ini menunjukkan bahwa perhitungan penentuan tarif rawat inap merupakan hal yang sangat penting, perhitungan tarif harus dilakukan secara teliti karena akan berdampak pada pendapatan rawat inap rumah sakit itu sendiri. Pembebanan biaya dalam penentuan tarif rawat inap harus dilakukan secara akurat sehingga dapat memberikan manfaat jangka panjang bagi rumah sakit. Penetapan tarif jasa rawat inap dengan menggunakan metode ABC System ini sangat dianjurkan untuk digunakan pada
RSUD Kabupaten Buleleng, karena dapat memaksimalkan pendapatan dari sektor rawat inap.

\section{REFERENSI}

Amirah Said Baashen, 2011. Analisis Perbandingan Penetapan Tarif Rawat Inap Rumah Sakit dengan Metode Tradisional dan Metode ABC Serta Implikasinya Terhadap Pendapatan Rawat Inap Rumah Sakit: Studi Kasus Rumah Sakit Muhammadiyah Bandung. Skripsi (tidak diterbitkan). Jurusan Akuntansi, FPEB, Bandung.

Blocher, Edward J, David E Stout, dan Gary Cokins. 2011. Manajemen Biaya: Penekanan Strategis. Buku Satu. Diterjemahkan oleh David Wijaya. Jakarta: Salemba Empat.

Carter, William K. 2009. Akuntansi Biaya Edisi 14. Buku Satu. Diterjemahkan oleh Krista. Jakarta: Salemba Empat.

Cooper \& Kaplan. 1991. "Penentuan Cost Driver". Tersedia pada http://www.viciouslisme.blogspo t.com/2010/06/[diakses tanggal 21 Desember 2016].

Hansen \& Mowen. 2009. Akuntansi Manajerial. Edisi 8. Jakarta: Salemba Empat

Horngren, Datar, dkk. 2008. Akuntansi Biaya (Penekanan Manajerial). Edisi 11.

Kamaruddin, Ahmad. 2013. Akuntansi Manajemen. Edisi Revisi.

Mulyadi. 2012. Akuntansi Biaya. Edisi 5. Yogyakarta : UPP STIM YKPN 
Mulyadi. 2014. Sistem Akuntansi. Yogyakarta: Salemba Empat

Supriyono. 2002. Akuntansi Biaya dan Akuntansi Manajemen Untuk Teknologi

Supriyono. 2012. Akuntansi Biaya. Yogyakarta: BPFE

Tunggal, Amin Widjaja. 2009. Pengertian Activity Based Costing System.

tersedia di http://mbegedut.blogspot.com/ 2012/04/abc-activity-basedcosting-menurutpara.html\#.UOj8apHtcdU. [Diakses tangal 18 Desember 2016].

Yulianti. 2011. Penerapan Activity Based Costing System Sebagai Dasar Penetapan Tarif Jasa Rawat Inap (Studi Kasus Pada RSUD H.A Sulthan Daeng Radja Bulukumba). Skripsi (tidak diterbitkan). Jurusan Akuntansi, Fakultas Ekonomi, Universitas Hasanuddin, Makasar.

Supriyono. 2002. Akuntansi Biaya dan Akuntansi Manajemen Untuk Teknologi Maju dan Globalisasi. Edisi 2. Yogyakarta: BPFE 